\title{
Articles
}

\section{Learning to be a Teacher: Development of EFL Teacher Trainee Interactional Practices}

\section{Yuri Hosoda (細田由利) \\ Kanagawa University \\ David Aline \\ Kanagawa University}

Applying Conversation Analysis (CA), this longitudinal study examines how teacher trainees developed their classroom interactional practices in an elementary school and constructed their identities as teachers over a 19-month period. The analysis focuses on two Japanese university students participating as teacher trainees in English Activities classes at an elementary school. Over 30 hours of classroom interaction were video recorded and analyzed in detail. Observation of the data revealed that through participation in this particular community, the trainees developed classroom interactional practices in two areas: provision of assessments to students and initiative in giving directions. As the trainees' interactional practices evolved, there were changes in their social actions in becoming teachers. This study demonstrates the positive effects of on-site training, and delineates the processes fledgling trainees undergo in transition to becoming fully participating teachers.

本研究では小学校の英語活動の授業において英語教育サポーターとして活動する大学生が 19ケ月間の間にいかにして教室相互行為の慣行を身につけ、教師としてのアイデンティティを構 築していったかを会話分析の手法を用いて長期に渡って検証した。分析は横浜市の某小学校で 英語活動に英語教育サポーターとして参加する大学生2名に焦点を当てた。検証の結果、19ケ 月間の間に児童の発話に対する口頭評価の仕方とおよび児童への口頭指示の仕方において2名 の英語教育サポーターの成長がみられた。また、教室でのやりとりを学んでいくと共に、教師とし

JALT Journal, Vol. 32, No. 2, November 2010 
てのアイデンティティも彼らの相互行為活動の中に垣間見られるようになつた。本研究は現場で の教育実習の有効性を示すと共に英語教育サポーターがその教育現場で徐々に駆け出しのサ ポーターから一人前の教師のようになっていく様子を描写した。

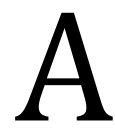

pplying Conversation Analysis (CA) as an analytical resource, which requires microanalysis of interaction from a data-driven emic (participants') perspective, this longitudinal study examines how teacher trainees developed their classroom interactional practices in an elementary school and constructed their identities as teachers over a period of 19 months.

In response to repeated calls for employing CA to attempt to understand learning from a longitudinal perspective (see Hall, 2004; Kasper, 1997, 2004; Mori \& Markee, 2009), some recent research applying CA has examined second language learners' change in participation over time through a microanalysis of institutional language learning interaction (see Hellermann, 2006, 2007, 2009; Young \& Miller, 2004). Hellermann (2006) tracked two learners for a period of 30 weeks and demonstrated how their interactional practices developed from peripheral to more engaged participation. In a further study, analyzing data covering 18 to 27 months, Hellermann (2007) outlined the changes learners made in interactional practices as they incorporated, into their own production, classroom discursive practices for opening pair tasks. Likewise, Young and Miller (2004), observing writing tutorials, provided analysis showing how, over four writing conferences, a learner moved to fuller participation in an unfamiliar discursive practice.

Drawing on perspectives of situated learning (Lave \& Wenger, 1991), the above studies conceptualized learning as resulting from learner participation in and adaptation to the social practices of a community. In this view, learners become competent participants as they move from peripheral to more engaged participation. The present study takes a further step in this line of research by using CA to examine how the interactional practices and identity orientations of teacher trainees change over time. Informed by research in the area of language socialization (e.g., Ochs, 1989, 1996; Ochs \& Schieffelin, 1984; Schieffelin \& Ochs, 1986), the present study is premised on the view that learning can beneficially be perceived as change in participation patterns. It also seeks to elucidate the transition of novice interactants from peripheral participation to full participation in a linguaculture and thereby ascertain how they evolve into expert members in a specific community.

From a CA perspective, this paper discusses changes over time in deployment of assessments and directives by two teacher trainees as manifested 
by their identity orientations. In CA research, the identity orientations of participants in interaction are discussed only when such identities are "demonstrably relevant to the participants, and at that moment - at the moment that whatever we are trying to provide an account of occurs" (Schegloff, 1992, p. 109). Therefore, our a priori knowledge that one participant is an experienced worker and the other participant is a novice worker should not influence our analysis, which is founded upon stable characterizations of the participants throughout interaction. Whether such characterizations are relevant at any given moment in the interaction is determined by the participants themselves through their observable talk and other conduct. In that sense, CA studies take a radically emic perspective (Markee \& Kasper, 2004). Another facet to consider when we examine identities is that someone who displays a certain set of characteristics can be treated as a member of the category or identity with which those characteristics are commonly associated (Antaki \& Widdicombe, 1998). In institutional talk, "specific action choices can index particular institutional stances, ideologies and identities that are being enacted in the talk" (Heritage \& Clayman, 2010, p. 18). Thus, in language classrooms, particular ways teachers and students talk is one aspect of how the institution of the classroom is realized or reproduced, and "talking in these ways is a part of being a teacher or a student .... These roles are enacted by talking in these ways" (Heritage \& Clayman, p. 32).

In the present study, we will demonstrate through microanalysis of interaction how two teacher trainees demonstrably transform their identity orientations as teachers from "novice" to "expert" or "near-expert" by explicating their deployment of assessments and directives.

\section{Data}

The analysis focused on two Japanese university students from among a group of approximately 14 participating as teacher trainees in English as a foreign language classes at an elementary school in Yokohama. The city government of Yokohama, going beyond the national curriculum, established guidelines which requested elementary schools to hold English Activities classes for all grades (Grade 1 to Grade 6) from the academic year 2007. As current Japanese elementary school teachers lack experience in teaching English (see Hogan, 2004; Kelly, 2002; Murphey, Asaoka, \& Sekiguchi, 2004; Takagaki, 2003) and there are not enough native-speaking teachers available, some elementary schools have requested assistance from local universities. 
Among the $14^{1}$ university students who participated as teacher trainees at one elementary school in Yokohama city, two English majors, Shota (SHO) and Makoto (MAK) (pseudonyms, both male), assisted in English classes 2 to 3 days per month for 19 months. At the time of the study, the student population of the elementary school was over 600 , with an average of 35 students per class.

Shota and Makoto worked with over 20 of the regular Japanese homeroom teachers (JHTs), data of six of whom are shown in the extracts presented here. In each class session, there was one Japanese homeroom teacher and in most of the classes also a non-Japanese expert speaker of English or assistant language teacher (ALT) present. (The ALT was not present in Shota's Time 2 class presented here.) During each visit to the school, the teacher trainees assisted in two or three English Activities classes.

Over 30 hours of classroom interaction were video recorded and analyzed in detail. Subsequently, the classroom interaction of the six classes presented here was transcribed using the transcription system developed by Jefferson (2004), the one most commonly used in Conversation Analysis. In this longitudinal study, three time slots each from 40 classes taught by Shota and 70 classes taught by Makoto were selected to capture the 19-month time frame of the project. Then classes were randomly selected from the pool of recorded classes within each of those three time slots. The exact dates of each time slot are shown in Table 1.

Table 1: Dates of Visits

\begin{tabular}{lcccc}
\hline $\begin{array}{l}\text { Teacher } \\
\text { trainee }\end{array}$ & $\begin{array}{c}\text { Time } \\
\text { slot }\end{array}$ & Date & $\begin{array}{c}\text { Number of } \\
\text { visit }\end{array}$ & Grade level \\
\hline Shota & 1 & Sept. 20, 2007 & 1st visit & 5th grade \\
Shota & 2 & Sept. 25, 2008 & 10th visit & 1st grade \\
Shota & 3 & Jan. 29, 2009 & 15th visit & 3rd grade \\
Makoto & 1 & Sept. 25, 2007 & 1st visit & 3rd grade \\
Makoto & 2 & July 2, 2008 & 15th visit & 4th grade \\
Makoto & 3 & Feb. 16, 2009 & 30th visit & 2nd grade \\
\hline
\end{tabular}




\section{Method}

To analyze the data, we mainly employed the framework of CA but also incorporated aspects of sociocultural theory and language socialization.

Conversation Analysis developed in part as a reaction to the a priori theorization and ad hoc analysis of mainstream American sociologists in the 1960s. A fundamental principle of CA methodology maintains that it makes no a priori assumptions about the data. Approaching the data with preconceived notions or coding schemes, no matter how incisive the researcher may be, constrains observation of the actual phenomena. According to Pomerantz and Fehr (1997), "it (CA) rejects the use of investigator-stipulated theoretical and conceptual definitions of research questions" (p. 66). Consequently, research questions arise from the data itself and its particularities.

As a counter to the deficiencies of a priori theorization, CA methodology employs as a basis for data analysis unmotivated exploration: the systematic inspection of audio and video recordings along with finely detailed transcripts of uncontrived interaction, focusing on revealing participants' micropractices through their orientations to sense making and shared understanding of their own interaction as embodied in the minute details of their talk and other conduct.

Initially, the data in this study were transcribed, then a number of general observations were framed about the interaction through analysis of both the transcribed and recorded data, following which an interactional phenomenon of interest was identified through reanalysis of the data.

However, as He (2004) noted in her application of CA to research on L2 learning and teaching, CA does not directly address learning and CA's exclusive focus on observable behavior at the moment of social interaction may pose difficulties for documenting change of behavior over an extended period of time. Therefore, for the purposes of this study, we adopted some concepts from a sociocultural theory (SCT) of learning. Like CA, SCT views knowledge and cognition as being socially shared and distributed among interactants (e.g., Donato, 2004; Lantolf \& Appel, 1994; van Lier, 1998). Unlike CA, SCT directly tackles the issue of learning: Based on the assertions of Activity Theory, SCT proponents argue that social interaction leads to language acquisition as learners internalize language through the creative construction of language.

Another approach to the issue of learning in situ is to incorporate the ideas of language socialization. For example, He (2004) integrates language socialization (e.g., Ochs, 1989; 1996; Ochs \& Schieffelin, 1984; Schieffelin \& Ochs, 1986) into her CA-inspired study of Chinese language classrooms. Although language socialization emphasizes the analysis of interaction as 
much as CA does, the basic concern of language socialization is human development and growth. According to Schieffelin and Ochs (1986), language socialization works bidirectionally as language functions as a medium or tool in the socialization process: "socialization to use the language" and "socialization through the use of language" (p. 167). In the socialization process, novices acquire the knowledge, orientations, and practices that enable them to participate effectively and appropriately in a particular community. Acquisition is realized mostly through the use of language, the major symbolic medium for communicating and negotiating cultural knowledge (Garrett \& Baquedano-López, 2002).

The current CA study also incorporates conceptualization of language socialization and documents the teacher trainees' socialization process through the use of language in a particular activity. Specifically, the study demonstrates how teacher trainees develop their identities as teachers through the deployment of directives and assessments in elementary school English Activity classrooms over an extended period of time.

\section{Analysis and Discussion}

Emerging from the analytical practice of unmotivated looking, analysis revealed development of the trainees' classroom interactional practices over time in two areas: (a) provision of assessments to students, and (b) initiative in giving directives. The trainees' interactional practices and identities as teachers are shown to be transformed through actual participation in the classroom community. The identity orientations of the trainees were manifested in the changes in their classroom interactional practices as they functioned with the homeroom teachers, the assistant language teacher (the same ALT throughout this data set), and students. The transition from peripheral participation as visitors to more engaged participation as nearexpert teachers was publicly demonstrated in the classroom interactions.

\section{Assessments}

Assessment deployment was one aspect of the interaction that came to the fore during analysis of the video and transcripts. In spontaneous, naturally occurring first language interaction, an activity common to speakers and recipients is some sort of evaluation of referents: the people, objects, and events being discussed (Goodwin \& Goodwin, 1987). These evaluations, commonly termed assessments, can be analysed as structural units such as adjectives; suprasegmental phenomena such as intonation; and speakers' 
acts, or assessment actions, in which the emphasis is on an entire speech act. An example of assessment in ordinary conversation is provided in Extract 1 from Pomerantz (1984, p. 57). In this extract, following J's suggestion to test the water, $\mathrm{R}$ makes a series of assessments.

\section{(1) (VIYMC 1:4)}

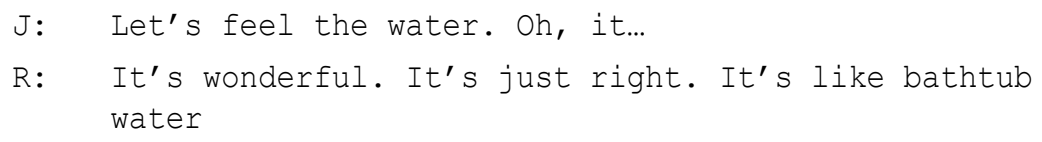

According to Pomerantz (1984), "assessments are produced as products of participation; with an assessment, a speaker claims knowledge of that which s/he is assessing" (p. 57). Therefore, the teacher trainees' assessment of the student performance purportedly displays their full participation in the classroom activity at hand as well as their sufficient knowledge of what the activity is for and about. Moreover, as Heritage and Raymond (2005) and Raymond and Heritage (2006) demonstrated, production of assessment reflects epistemic rights to evaluate the third party (e.g., a grandmother of the person being assessed has greater rights to assess than her friend). The speaker can declare greater rights to assess by producing assessments first or upgrading the assessments at times when the other interactant has produced assessment first. As demonstrated below, at later stages of this study, the teacher trainees began to claim their rights to assess student performance by occasionally proffering assessments first, or by upgrading their follow-up assessments when the other teacher(s) produced assessments first. In the institutional interaction of the classroom, assessments have traditionally been seen as being proffered by the teacher in the feedback turn of Initiation-Response-Feedback (IRF) sequences (Sinclair \& Coulthard, 1975). Therefore, providing assessments to student responses shapes one's identity as a teacher.

In the transcripts, SHO refers to Shota, MAK refers to Makoto, ALT refers to the near-native assistant language teacher, JHT refers to one of six Japanese homeroom teachers (but only one in each class), EV refers to everybody in chorus, and $\mathrm{S}$ refers to a student.

\section{Shota}

Shota displayed significant change in the way he used assessments in this data set. At Time 1, he produced no verbal assessments at all during any in- 
teraction in the classroom and only aligned with the assessments of the ALT and JHT through applause following their initiation, or displayed embodied positive assessments through head nods.

In Extract 2, Shota models a dialog with a student at the front of the class. However, even though Shota is interacting with the student, it is the JHT and ALT who implement the assessments.

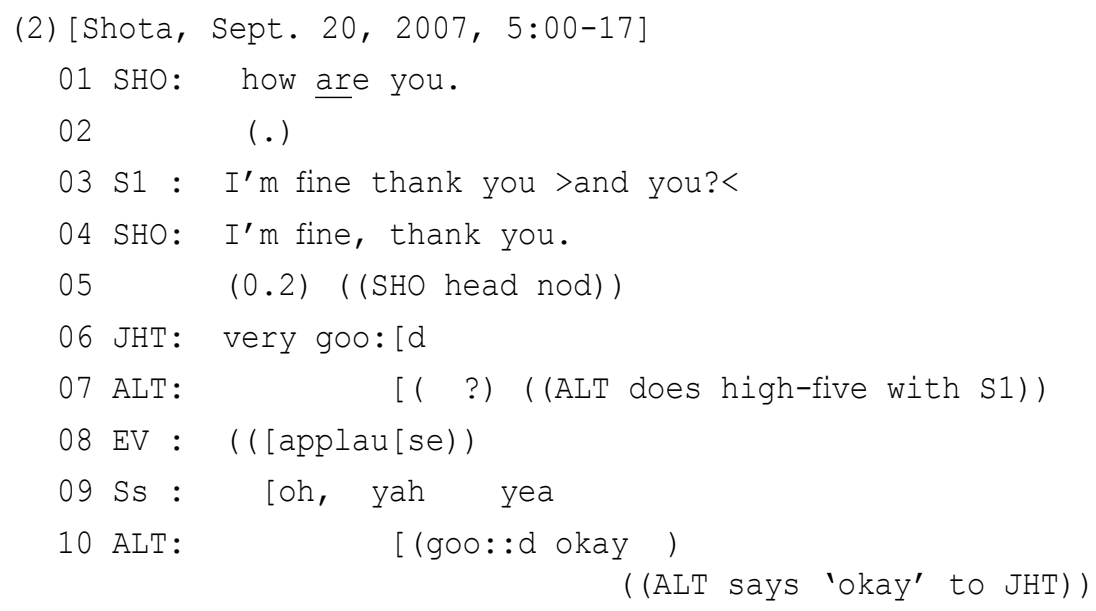

Prior to this extract, the ALT requests Shota to say "how are you" to one of the students. Upon the ALT's request, Shota asks the question to S1 (line 1). By asking Shota to perform some of the classroom teaching tasks, the ALT treats Shota as an assistant, and by implementing the ALT's request, he himself shows his orientation to being a teacher trainee through his assistance. As Shota completes the dialog in line 4, he begins to move out of the front of the classroom to the side, giving a slight head nod to the student. At this point, the JHT provides an assessment with "very goo:d" and the ALT initiates and co-completes an embodied assessment with the student. Shota then joins in with the applause initiated by the JHT; clearly he is not orienting to the same type of teacher identity as the JHT and ALT as the feedback turn of the traditional IRF sequence is noticeably absent from his interaction. Shota's nod in line 5 shows that he treats the student's response as appropriate. However, he does not verbalize the assessment. By refraining from giving assessment verbally, it is possible that he does not view himself as a person who possesses the right to judge the student's performance. On 
the other hand, the JHT verbalizes the positive assessment, publicly demonstrating that she is in a position to judge the student performance.

Later in the program, at Time 2, however, Shota does provide assessments: when working with students on a one-to-one basis; when following up on the JHT's assessments by translating them into English; and when put in charge of leading the class, as shown in Extract 3.

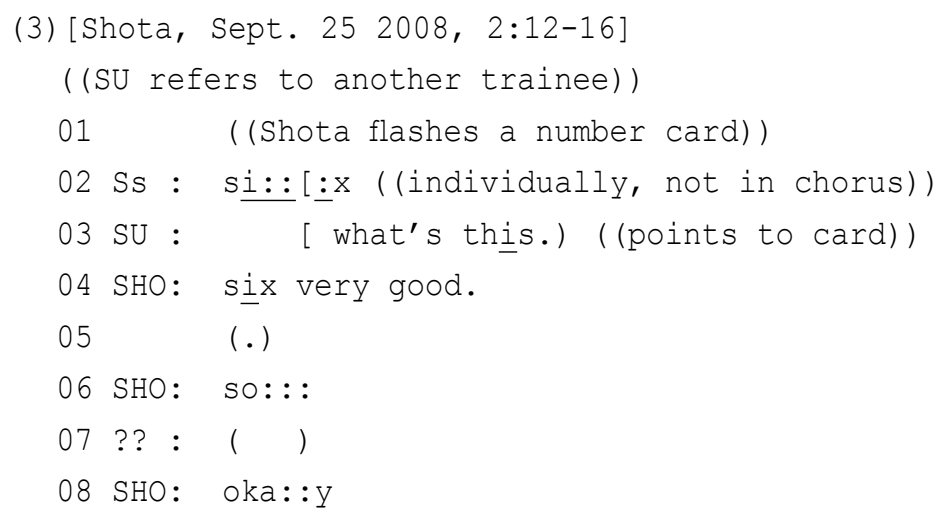

In Extract 3, after Shota flashes a number card and the students call out the number, he receipts (receives and acknowledges) their response through repetition (a process identified in Greer, Bussinger, \& Mischlinger, 2009), and then deploys an assessment, "very good." Although both Shota and SU were put in charge of the teaching activity, it was Shota who produced the assessment. This shows that Shota orients to the fact that it is he, not the other trainee, who has a right to judge students' performance, at least when the trainees are in charge of teaching. This is an interesting contrast with Time 1 when he did not produce any assessments even when he was in charge of some classroom teaching tasks. However, in Time 2, while Shota often gave assessments during individual work with students, he only provided assessments in teacher-fronted activities when he was clearly assigned to lead the class by the ALT or JHT. Even so, at this stage these were still rarely heard.

By Time 3, Shota displays greater variety in assessments when working individually with students and when following up on the JHT's and ALT's assessments. His follow-up assessments are always upgrades, just as second assessments are in first-language conversations (Pomerantz, 1984). Moreover, he now displays greater participation and identity as one of the group of teachers rather than as a visitor or assistant in that he deploys assessments 
even when the JHT and ALT are clearly in charge of the main classroom activity (Extract 4).

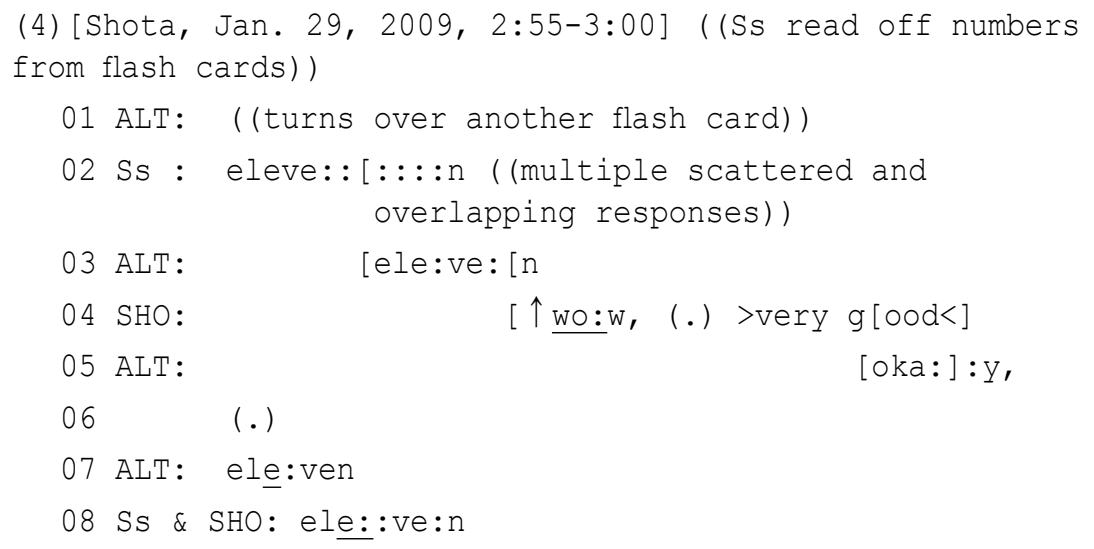

Here, Shota is kneeling off to the side as the JHT and ALT manage the main activity of turning over flash cards of numbers. As the students call out the number, the ALT receipts it through repetition, line 3. Shota then produces " $\uparrow$ wo:w," in line 4, which appears to be what Goffman (1981) termed a response cry, a brief emotional expression, before accounting for the surprise with a compressed assessment, ${ }^{2}$ which is overlapped by the ALT's basic assessment token "oka::y," line 5. By producing an assessment of student performance even when the JHT and ALT are standing in front of the classroom managing the main activity, Shota displays his orientation to being in a team of teachers along with the JHT and ALT. At this point in the program, Shota repeatedly produced assessments in a greater variety of sequential environments whether or not he was in charge of the main activity; his follow-up assessments were always upgrades, and almost all of his assessments were rushed as he attempted to squeeze them into the fast-moving interaction of the classroom.

Through examination of Shota's development in assessments, a clear change in his identity orientation was observed. In Time 1, by not giving assessment even when he was in charge of a teaching activity, he treated himself as someone who did not possess the right to judge student performance, but was rather just a teaching assistant who was trying to accomplish an assigned task. In Time 2, by giving some assessments when the ALT or JHT was not the main teacher of the activity but Shota was, he oriented to himself as someone who possesses the right to make judgments of student 
performance. And in Time 3, by deploying assessments even when the ALT or JHT was the main teacher of the activity, he treated himself as one of the teachers in the classroom, in possession of the right to give feedback on student performance.

\section{Makoto}

In Time 1, the assessments Makoto produced were limited to clapping as one form of positive assessment (for more on forms of assessment, see Hosoda \& Aline, 2010a, 2010b), and simple assessment tokens such as "good job" and "very good," which were exact copies of assessments produced by the ALT and JHT.

In Extract (5), Makoto has been assigned by the ALT to ask a student a question, and he chooses S13 to answer the question.

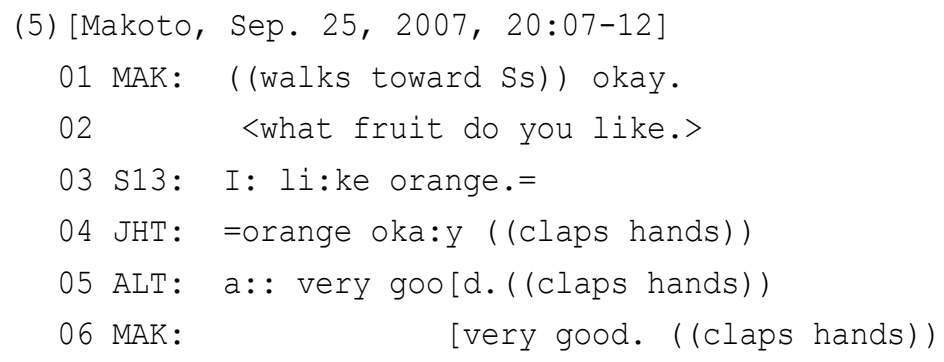

Although in line 2 it is Makoto who directs the question to S13, in line 3 the JHT is the first to accept S13's answer. The ALT's assessment follows the JHT's assessment and then in line 6, Makoto's assessment is exactly the same form as the ALT's assessment, "very good." and clapping.

In this extract, by assigning Makoto to do some of the teaching, the ALT treats Makoto as her teaching assistant, while by complying with the assignment and carrying out the task, Makoto orients to being an assistant for the class. The JHT's deployment of assessment that immediately follows student performance in line 3 demonstrates her orientation to being in charge of the class even when somebody else is leading the class. The ALT's assessment also displays her orientation to being a teacher by producing the assessment. As Makoto is the one who is leading the class and who asked the question in line 1 , he is in a position to produce the assessment in the turn following S13's response. However, Makoto provides assessment only after 
assessments by the JHT and ALT, and it is in the same format as the ALT's assessment. Providing assessment in this format and position may show his uncertainty about having the right to produce assessments and how assessments should be produced. However, his deployment of the assessment demonstrates his orientation to being in a team of teachers.

In Time 2, Makoto started producing a greater variety of assessments, such as "excellent," "perfect," "good," and "good job." These assessments were not simply copies of those produced by the ALT or JHT, and his assessments occasionally occurred sequentially earlier than the ALT's or JHT's assessments. (Extract 6)

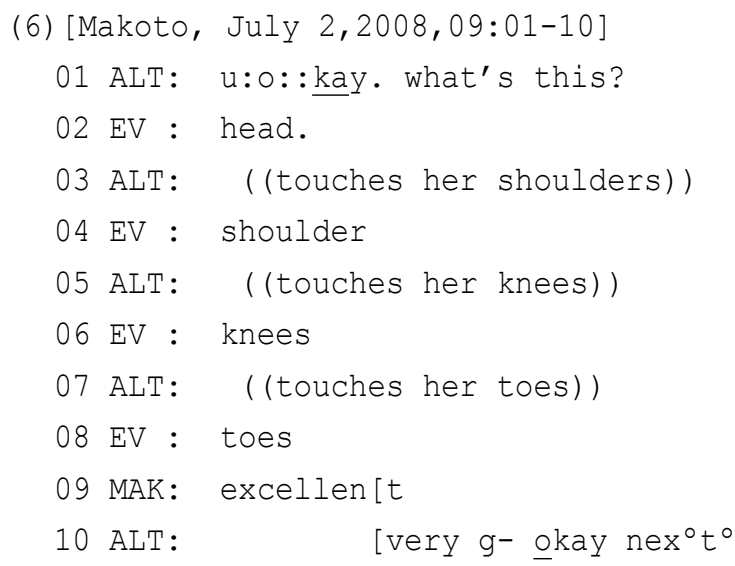

In Extract 6, in lines 1 to 8, the ALT asks the whole class what each part of the body is called in English and students answer the question in chorus. However, in line 9, when the activity is finished, it is not the ALT but rather Makoto who first produces an assessment token, "excellent". In line 10, the ALT starts to produce an assessment, "very g-" but cuts it off and produces "okay nex $\mathrm{o}^{\mathrm{o}}$ ", actions which indicate a shift of activity. As it occurs after Makoto's assessment, the ALT's assessment is considered a follow-up assessment. Pomerantz (1984) notes that assessments following somebody else's assessments are usually designed to be upgrades. Therefore, in this position, the ALT's assessment should be an upgrade. One reason the ALT cuts off her own assessment may be that her assessment, "very good," is not an upgrade of Makoto's assessment, "excellent". Through the way that Makoto produced his assessments, he demonstrated his orientation to being one of 
the teachers even when he was not the main teacher of an activity. Moreover, the ALT's cutoff of her assessment and shift of the activity demonstrates her acceptance of Makoto's assessment and therefore her acceptance of his role as a teacher.

Makoto continued to use a variety of assessment tokens in Time 3. He often produced assessment tokens by himself, without the JHT or ALT having produced one, or produced assessments before the ALT or JHT produced theirs. Moreover, when the ALT's or JHT's assessments occurred before his assessments, Makoto upgraded his assessments, as shown in Extract 7.

(7) [Makoto, Feb. 16, 21:57-22:14]

((JHT has asked students how many marbles are in the envelope and students are making a guess.))

01 ALT: a: : hidaka: ¿

02 S1 : ( (stands up)) five?

03 ALT: five ah >okay okay okay< ((stops S1 from sitting down))

04 JHT: up.

05 S? : wakannai. "I don't know"

06 S1 : ${ }^{\circ}$ five $^{\circ}$

07 ALT: ${ }^{\circ \circ} \mathrm{Six}^{\circ 0}=$

08 S1 : $\operatorname{six} .=$

09 ALT: =six?

10 (0.2) ((JHT looks inside the envelope))

11 JHT: ye:s. [that's right.

12 ALT: [u[OH:: ::::: ((claps hands))

13 MAK: [OH:: ::::: ve:ry good. excellent. ( (claps hands))

In Extract 7, the JHT is standing at the front of the classroom holding an envelope that contains marbles and asks students to guess how many marbles there are in the envelope. The ALT is also standing at the front of the classroom assisting the JHT. Makoto is standing behind the students. In line 8, S1 makes a second guess and utters "six." In response to this answer, 
the JHT checks the inside of the envelope and says, "ye:s." Hearing the JHT's "ye:s.", both the ALT and Makoto produce prolonged ohs while the JHT is producing an assessment token, "that's right." After producing "oh::::::::", Makoto adds assessment tokens, "ve:ry good." and "excellent." which are upgraded positive assessments of the JHT's version of assessment "that's right." Again, his assessment occurs when other teachers are leading the class, showing his orientation to being one of the teachers. Moreover, his upgraded followup assessment shows his full rights to provide and confidence in deploying the assessment (Heritage \& Raymond, 2005; Raymond \& Heritage, 2006) as well as his mastery of how to produce the assessment.

During the time period examined, the way Makoto produced assessments changed from doing assessments peripherally, following the JHT or ALT, to doing assessments fully by himself on his own initiative. Providing assessments by himself or upgrading the JHT's or ALT's assessments displayed his identity as a fully participating teacher.

Both Shota and Makoto moved from only infrequent simple assessments following on the ALT's or JHTs' initiation in Time 1 to repeated and varied assessments in Time 3. In Time 3, both trainees produced assessments sequentially earlier than the ALT or JHT even when they were not the main teacher of the teacher-fronted activities. This change publicly demonstrates their transition from being guests or assistants in the classroom to being teachers.

\section{Directives}

Another aspect of change we noticed over the three time periods was a change in the way Shota and Makoto provided directives in the classes. Traditionally, directives have been studied from the speech act perspective and have been examined as a single utterance or as a pair of utterances (directive-compliance/noncompliance). Directives have been seen as utterances produced to get someone else to do something (Austin, 1962; Searle, 1976), and include offers, requests, orders, prohibitions, and other verbal acts that ask for goods or attempt to bring about changes in activities of others (Ervin-Tripp, 1976; Ervin-Tripp, O'Connor, \& Rosenberg, 1984). Recently, however, directives have been investigated from a CA perspective, ${ }^{3}$ demonstrating that directives and their actions are better understood through examination of their trajectories constituted in extended sequential contexts (Cekaite, 2010; Goodwin, 1990, 2006; Goodwin \& Goodwin, 2001).

Ervin-Tripp et al. (1984) noted that "a speaker who is high in esteem has the right to receive verbal deference from others and can make control 
moves boldly, without offering deference to those who are lower in esteem" (p. 118). Providing directives to others through ordering and summoning is considered to be universally linked to a high ranking status (Ochs, 1996). Thus, the action of uttering directives and complying (or not complying) to directives can be taken as "category-bound activities" (Sacks, 1972) that invoke pairs of categories that consist of a person who is in a higher rank and a person who is in a lower rank, such as parent-child, boss-employee, doctor-patient, or teacher-student. In a classroom context, by issuing directives, the speaker orients to herself or himself as a teacher while constituting the receivers of the directives as students. As discussed below, this kind of orientation by Makoto and Shota was initially absent but manifested itself at later stages.

\section{Shota}

During Time 1, Shota displayed an orientation to himself as an assistant: repeatedly shushing the students when the ALT looked to him for assistance in getting the students to become quiet, displaying bodily agreement with the ALT's directives through head nods and hand gestures, or helping to form groups of students for small group activities. His only verbalized directives were produced outside of the teacher-fronted arena when he moved into the crowd of students and formed groups or directed them to stand up, as in Extract 8.

(8) [Shota, Sept. 20, 2007, 3:22-52]

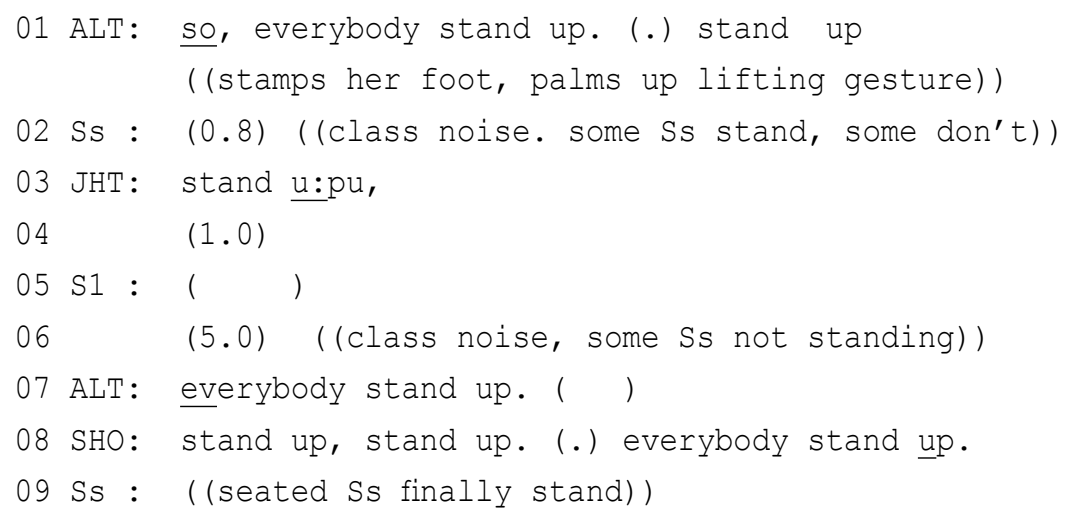


Making the transition to another activity, the ALT directs the students to stand up in line 1, stamping her foot and producing a lifting gesture with palms up. The JHT then repeats the directive. Some of the students stand, but many are still seated. After about 5 seconds the ALT repeats her directive with the same gesture. Shota then moves into the middle of the crowd, deploying the same phrases and gestures as the ALT for the directive. The position (after the ALT and JHT) and format (same as the ALT and JHT) of Shota's directives demonstrate his orientation to being an assistant teacher in the class, but the production of directives also shows that he orients to himself as being one of the teachers as opposed to being one of the students. ${ }^{4}$

Shota began in Time 2 to expand on his repertoire of directives through repetition with expansion of the Japanese teacher's production, while continuing to deploy directives in individual work with students. In Extract 9, the class is again beginning a singing activity and the JHT directs the students to stand up.

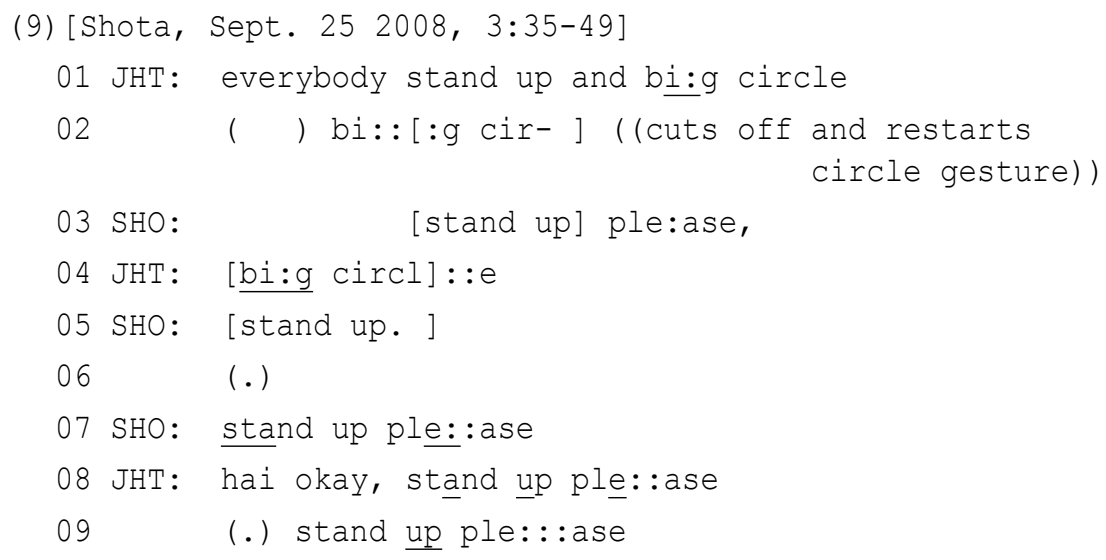

The JHT switches to a new activity, directing the students to stand and form a circle. As the JHT recycles "big circle" (line 2), Shota calls out a repeat of the directive (line 3) but with the addition of a politeness marker. Shota's repetition of the directive occurs in overlap with the JHT's repeat of "circle," and the JHT cuts off the phrase "big circle" and restarts his production of the phrase and circle gesture. When he recycles "big circle," his production again overlaps with Shota but the JHT survives the overlap through deployment of an extended vowel sound. ${ }^{5}$ Shota repeats with greater emphasis the politeness-marked directive, and the JHT then produces his directive 
again, twice, this time with the politeness marker added. Therefore, at Time 2 , Shota is still orienting to his identity as an assistant in that he repeats the directives of the main teacher, but he is taking a stronger stance with directives in that his repeat overlaps with the JHT's continued directive, and Shota is additionally orienting to his identity as an expert speaker of English by expanding on another's directives with marked politeness. The JHT too orients to this expertise by incorporating the marker into his own directive. The format of Shota's directives, which is slightly different from the JHT's directives, demonstrates his better understanding of how to formulate directives in the class as compared to Time 1 . By producing directives when he is not leading the class he demonstrates his orientation to being one of the teachers in the room.

A significant change in Shota's orientation to identity manifested itself by Time 3. Shota still assists through repeats of directives with slight expansions or paraphrases (back to your seats / sit down please), and deploys directives when put in charge of leading the class. But more than this, he begins giving directives of his own. This is an incipient orientation to his identity as a full-fledged member of the teaching community, as evidenced in Extract 10.

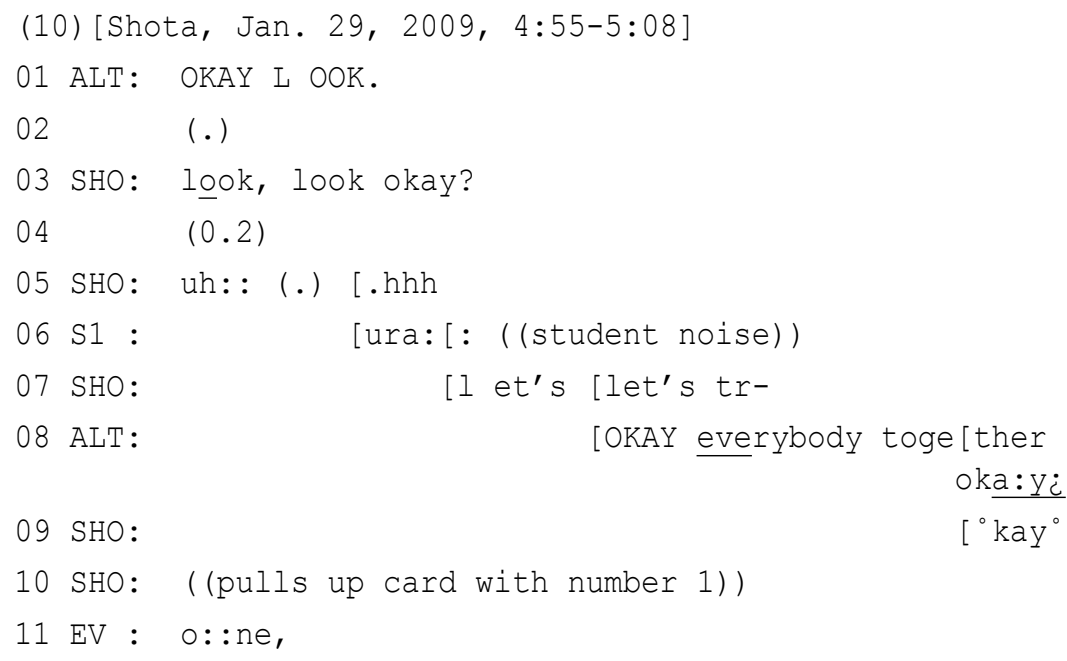

Here, the ALT along with the JHT, Shota, and another teacher-trainee are finishing explaining the rules for a small group game by showing for the 
last time how to pick up and read off the number cards. The ALT marks the change with a very loud call for attention in line 1, following which Shota repeats the directive twice. Shota has some difficulty in proceeding as indicated by the perturbation "uh::" and micropause in line 5 . After the pause and an in-breath, which shows he is preparing to produce a chunk of utterance, Shota initiates a directive, but it is not a repetition of another teacher's directive. In line 8, Shota says "l[et's", and is at a position of greatest grammatical control, a place of least turn transition relevance in that a verb is expected next. He then recycles "let's" and in overlap with his recycle the ALT produces a loud "OKAY" and stress on the first two syllables of "everybody". In consequence, Shota relinquishes his turn and aligns with the ALT as shown by his production of "kay" in quiet speech. This extract is one example of Shota beginning to deploy his own directives, not just repeat the directives of other teachers. Furthermore, although Shota orients to an identity as a teacher by initiating directives, he also displays an orientation to the ALT's expertness by dropping out of overlap in this crucial position of his own directives, crucial in two respects: in terms of the utterance level as he is at the point of maximal control of his utterance, and in terms of sequential position as it is at the point of initiating an activity.

\section{Makoto}

In Time 1, Makoto did not produce any directives to start tasks or facilitate students' performance in a task. He quietly listened to the ALT or JHT give directions to students. In Extract 11, the ALT gives directions to initiate a singing activity.

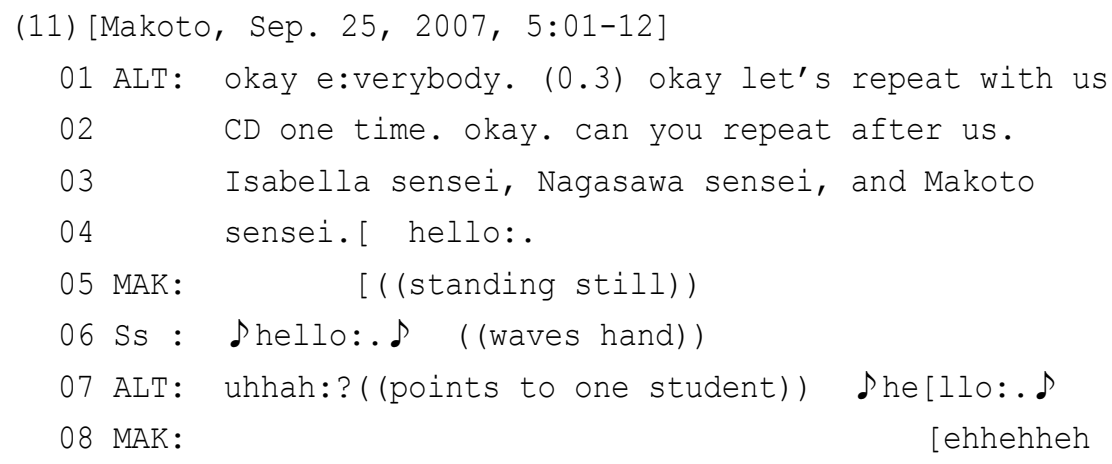




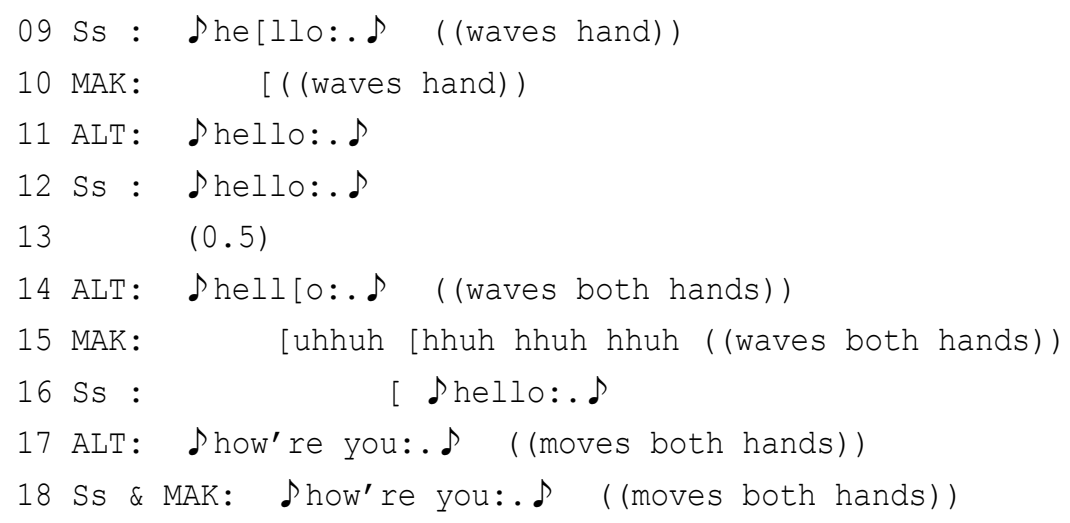

In lines 1 to 4 , the ALT produces a directive to students to start singing. Specifically, she directs students to repeat after the JHT, Makoto, and her. In this way, the ALT includes Makoto as one of the teachers in her directive in line 3. Although the ALT tells students to repeat after the JHT, Makoto, and her, Makoto does not perform the first pair part of the repetition sequence. In a repetition sequence, some utterance comes as a first pair part, and repetition of the first pair part should come as a second pair part. However, Makoto remains quiet up to line 15. Moreover, he does the second pair part nonverbally with the students, line 10 (overlapped with students' turn in line 9), reflecting his disorientation to being a teacher. Makoto's hand-waving in line 15 occurs just between the teacher's first pair part and students' second pair part, possibly indicating his uncertainty about whether he should act as a teacher or a student. Furthermore, in line 18, he produces the second pair part with the students as if he were one of them rather than one of the teachers. This demonstrates that he does not at this time orient to an identity as one of the teachers in the classroom.

In Time 2, Makoto frequently deployed a variety of directives both verbally and nonverbally. On some occasions, he took the initiative in providing directives, especially during singing activities. In those activities, Makoto collaboratively produced directives with the ALT and JHT by (a) repeating the directives produced by the ALT or JHT but in a louder voice, (b) slightly modifying what the ALT or JHT said, or (c) deploying directives in original forms. In Extract 12, the students are singing the "Seven Steps" song.

(12) [Makoto, July 2, 2008, 1:22-2:02]

01 ALT: ready: :? 


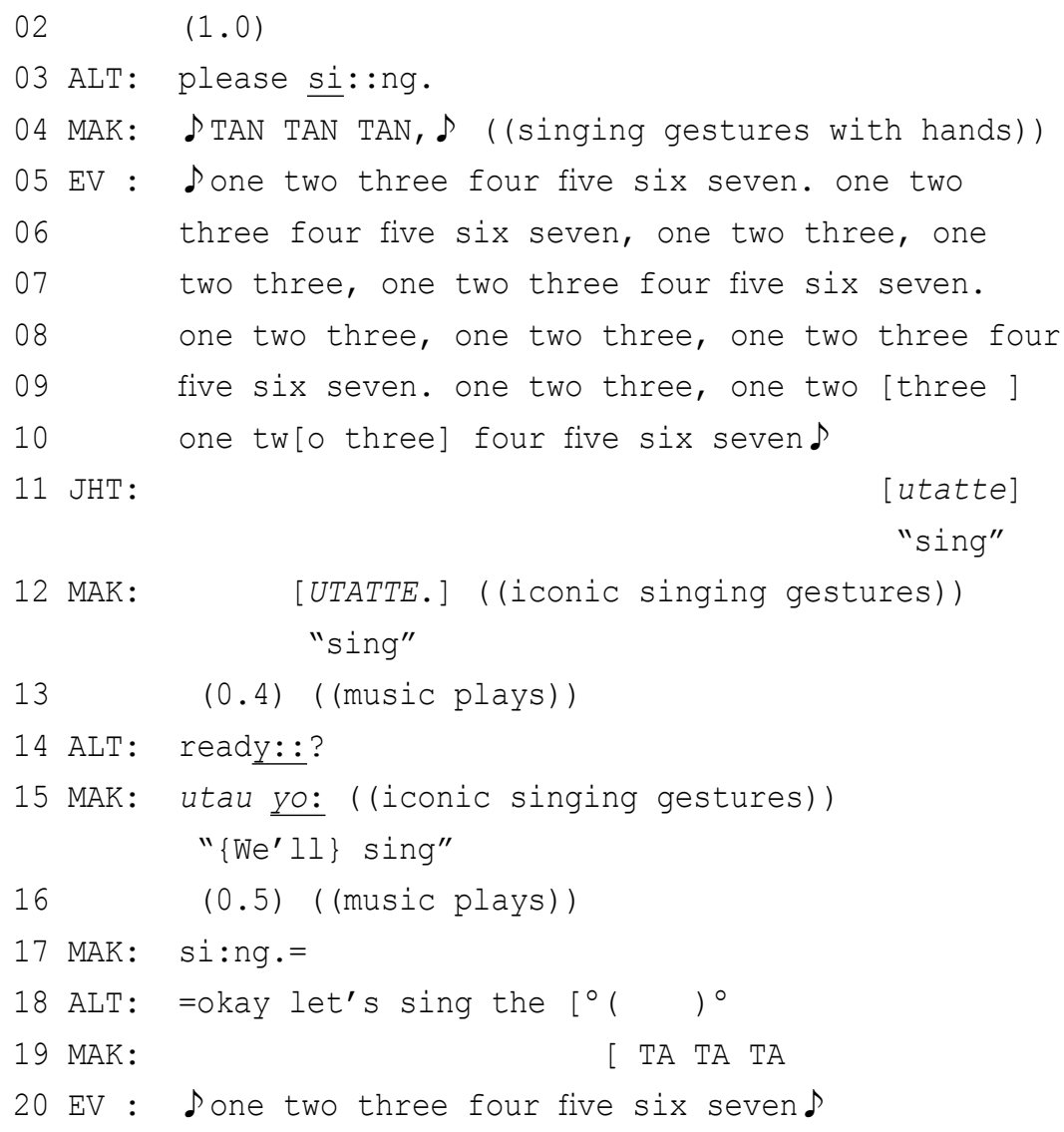

Right after the ALT's directive " please si::ng” (line 3), Makoto deploys a directive verbally and nonverbally in his own format (" D TAN TAN TAN, ১)" produced with singing gestures). This directive indicates to the students when to start singing and thus facilitates the students' performance of the activity. Toward the end of the first round of the song, in line 11, the JHT, speaking in Japanese, directs the students to sing, "utatte" (sing), and Makoto repeats the directive but in a louder voice. Between the first and second rounds of the song, in line 15, Makoto again directs the students in Japanese to sing, but this time with a slight modification, "utau yo:" (\{We'll $\}$ sing) with a singing gesture. After a pause, he produces a directive again but this time in English "si:ng." This directive by Makoto is a slight modification of the 
ALT's directive in line 3, "please si::ng." Producing the directive in his own form, repeating the JHT's directive in a louder voice, and modifying the ALT's or JHT's directives demonstrate that at Time 2 Makoto became confident of his right to direct students. Furthermore, by deploying directives collaboratively with the ALT and JHT, he orients to himself as one of the teachers.

In Time 3, Makoto continued to take the initiative in producing directives in singing activities. He also started providing directives in other types of activities. He often produced directives using words and expressions different from the ALT or JHT, and he sometimes produced directives by himself, not with the ALT or JHT or after them. In Extract 13, the students are practicing how to count in English. Before the beginning of the extract, the students were told to close their eyes while the teachers put paper apples in various places in the classroom. The students were supposed to count the apples and tell the teacher how many apples they saw in the classroom.

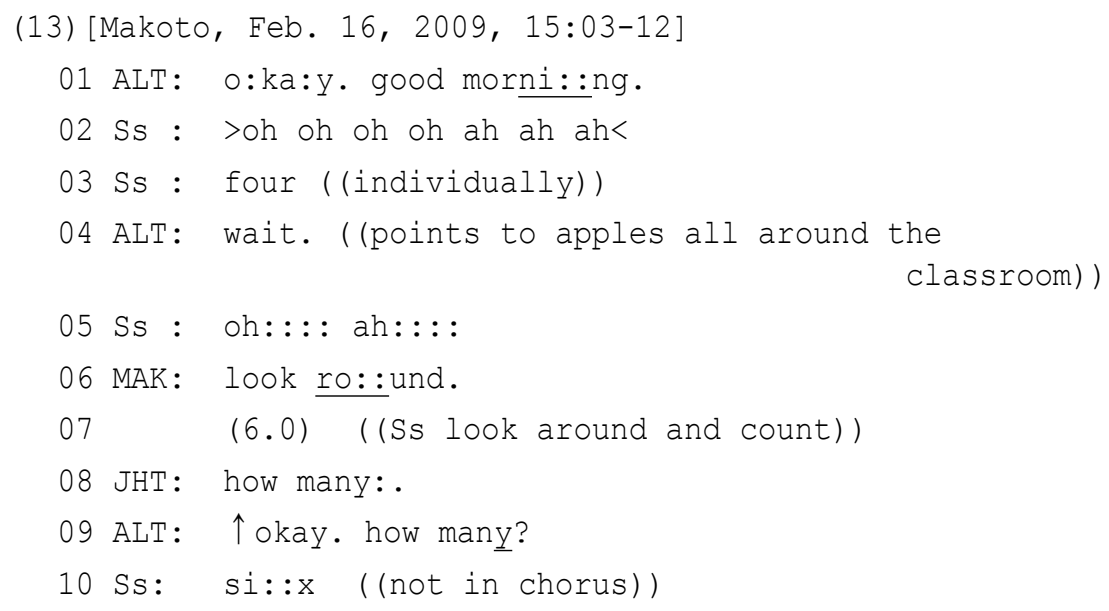

In line 1, the ALT produces "good morni:.ng.", which informs the students to open their eyes. Some students see the apples pasted on the board and say "four." Then the ALT says "wait." and points to the apples all around the classroom, and some students produce "oh:::: ah::::" and start looking around the classroom. Makoto produces "look ro::und.", which is a verbalized version of the ALT's nonverbal directive in line 4. The ALT's pointing in line 4 and Makoto's utterance "look ro::und." in line 6 perform the same action: directing or requesting the students to look around the classroom 
to find the paper apples. By verbalizing the action the ALT has already performed nonverbally, Makoto demonstrates his orientation to co-teaching and his identity as being in the same teaching team as the ALT. Students also view Makoto as a teacher: following Makoto's directive, all the students look around the classroom and start counting (line 7). As mentioned earlier, providing directives to others is considered to be universally linked to a higher ranking status (Ervin-Tripp et al., 1984; Ochs, 1996). Thus, by producing directives in the classes, Makoto demonstrated a higher rank and authoritative position with the right and privilege to direct students. In CA terms, he talked this higher rank into being. Moreover, in the later stages, producing directives in different forms from the ALT or JHT or by himself, Makoto demonstrated his at least equal or perhaps sometimes greater control over the class than the ALT or JHT.

In the case of directives, at Time 1 neither trainee produced self-initiated directives in whole-class activities. By Time 3, both Makoto and Shota attempted to deploy self-initiated directives in their own forms, and thus displayed their orientations as fully participating teachers.

\section{Conclusion}

This longitudinal study examined how two teacher trainees developed their classroom interactional practices in terms of assessments and directives and constructed their identities as teachers over a period of 19 months.

Emerging from the microanalysis of the data, observable changes were manifested by the two elementary school English teacher trainees in deployment of assessments during classroom activities. Initially, Shota aligned with the assessments given by the ALT and JHTs by joining in with applause and producing embodied assessments in the form of head nods, but without participating in any verbalization of the assessments. Makoto also echoed assessments deployed by the ALT and JHTs through his alignment with the applause they initiated, and also echoed their verbal assessments but only in the same form. By Time 2, a year later, Shota verbalized assessments when interacting individually with students, when translating the JHT's productions from Japanese to English, and when taking charge of whole-class activities. Makoto manifested change through deployment of a greater variety of assessments, and occasionally by deploying some assessments sequentially earlier than the ALT or JHT. Finally, over the period of 19 months covering the data collection analyzed here, both Shota and Makoto deployed assessments in a greater variety of sequential environments, many self-initiated or 
sequentially prior to the other teachers, while their follow-up assessments were always upgrades.

This study also described the two trainees' significant changes in deployment of directives. At the beginning, neither trainee verbalized directives in whole-class activities. Shota displayed bodily agreement with the ALT's directives through head nods and hand gestures, and he verbalized directives only outside of the teacher-fronted arena in the form of repeats of the ALT's or JHTs' directives, while Makoto did not publicly verbalize any directives in the class. In the later stage, the two trainees gradually began to display better understanding of how to formulate directives not only by repeating the ALT's or JHTs' directives but also by paraphrasing or expanding the ALT's or JHTs' directives; and by Time 2, Makoto occasionally deployed verbal and nonverbal directives in original forms. By the end of this investigation period, both Shota and Makoto expanded their repertoires of directives, and their verbal and nonverbal deployment of directives became more frequent. Furthermore, both of them at times attempted to initiate directives of their own.

As the trainees' interactional practices evolved, there was a change in their social orientations as teachers. Initially, the trainees participated peripherally and oriented mainly to themselves as assistants. However, as they were socialized into classroom culture and changed their interactional practices, they frequently displayed characteristics that are conventionally associated with teachers. Their orientations to their own identities as fully participating teachers were clearly displayed in the later periods. Moreover, the trainees' orientation in the later periods to being one of the teachers occasionally had some visible effects on interaction: The other teachers, as well as students, treated each of the trainees' assessments and directives as an action carried out by one with equal status as a member of the teaching staff. For instance, the other teachers let the trainees have opportunities to produce assessments and directives first and initiated new sequences after the trainees' assessments, and the students invariably complied with the trainees' directives. Over the 19-month period of this longitudinal study, the teacher trainees learned through interaction how to deploy assessments and directives in socially and culturally meaningful ways through participating in this particular community.

\section{Implications and Future Research}

While the importance of practical training in all fields of education is well established, this study provides evidence for the importance of 
teaching-training programs from a microanalysis of actual interaction. It demonstrates the positive effects of on-site teacher training, and delineates the processes fledgling trainees undergo in making the transition to fully participating teachers in learning to deploy previously learned language in actual classroom situations.

This research project also demonstrates the efficacy of the system of sending university students to participate as teacher trainees in elementary schools in Japan as their change over time leads to greater support for the elementary school teaching staff, better teaching for the elementary school students, and a benefit to society through an increase in the number of trained and competent teachers.

Future research will need to (a) examine the consequences of such teacher-training programs for the classroom teachers themselves as they assist the trainees in learning to be teachers, (b) appraise the educational impact on the students as they interact with the teachers and teacher trainees, and (c) scrutinize the interaction during the students' development, the trainees' evolution, and the responses of the teachers.

This study has further demonstrated that a microanalysis achieved through the application of CA methodology can reveal step-by-step changes in language deployment in a specific situation over time.

\section{Acknowledgments}

The research presented here was supported by Grant-in-Aid \#20520554 from the Japan Society for the Promotion of Science. We wish to thank the elementary school students and staff for allowing us to visit their classes, the teacher trainees who participated in the study, and two anonymous JALT Journal reviewers. Any inconsistencies in analysis or presentation remain ours.

\section{Notes}

1. The exact number of teacher trainees varied over the course of this 19-month study.

2. A response cry is an exclamatory interjection that provides a clue as to the state of the speaker. Goffman (1981) described it as "a natural overflowing, a flooding up of previously contained feeling, a bursting of normal restraints, a case of being caught off guard" (p. 99). He added that speakers may utter "a mocked-up response cry" (p. 117) to evoke 
the image of someone who has need of a particular response cry. In Extract 4 presented in this paper, Shota's cry, "?wo:w" (line 3) may not be a response cry that displays an eruption of spontaneous emotion, but a mocked-up response cry which evokes the image of someone who is being surprised. Shota may be deploying this mocked-up response cry deliberately (vs. spontaneously) to transmit a particular message to the students: He is purposely showing surprise at the unexpectedly good performance of the students, and by doing so he accentuates the positive assessment ">very good $<$ " that follows the cry.

3. In CA studies of ordinary conversation, the term "requests" has been used more often than "directives." However, in studies of conversation in which there is an asymmetrical relationship among participants such as parent-child interactions (Cekaite, 2010; Goodwin, 2006) the term "directives" has most often been utilized.

4. Lerner (1993) uses the term "association" to describe the "team-ness" of interactants when one speaks of "any assemblage of co-present individuals that are in any of various ways cast as a collectivity" (p. 214). A speaker may demonstrate membership of association by subsequently joining in the ongoing action. Shota, in Extract 8, subsequently joins in the ongoing action by producing the directives "stand up, stand up. (.) everybody stand up."

5. See Schegloff (2000) for resources interactants employ for resolving overlaps.

Yuri Hosoda, EdD, is an Associate Professor at Kanagawa University. Her research interests include conversation analysis and sociolinguistics.

David Aline, EdD, is a Professor at Kanagawa University. His research interests include conversation analysis for second language learning and use.

\section{References}

Antaki, C., \& Widdicombe, S. (1998). Identity as an achievement and as a tool. In C. Antaki \& S. Widdicombe (Eds.), Identities in talk (pp. 1-14). London: Sage.

Austin, J. (1962). How to do things with words. Oxford: Clarendon Press.

Cekaite, A. (2010). Shepherding the child: Embodied directive sequences in parentchild interaction. Text \& Talk, 30, 1-25. 
Donato, R. (2004). Aspects of collaboration in pedagogical discourse. Annual Review of Applied Linguistics, 24, 284-302.

Ervin-Tripp, S. M. (1976). Is Sybil there: Some American English directives. Language in Society, 5, 25-66.

Ervin-Tripp, S. M., O'Connor, M. C., \& Rosenberg, J. (1984). Language and power in the family. In C. Kramerae, M. Schulz, \& W. O’Barr (Eds.), Language and power (pp. 116-135). Beverly Hills, CA: Sage.

Garrett, P. B., \& Baquedano-López, P. (2002). Language socialization: Reproduction and continuity, transformation and change. Annual Review of Anthropology, 31, 339-361.

Goffman, E. (1981). Forms of talk. Philadelphia: University of Pennsylvania Press.

Goodwin, C., \& Goodwin, M. H. (1987). Concurrent operations on talk: Notes on the interactive organization of assessments. IPRA Papers in Pragmatics, 1(1), 1-54.

Goodwin, M. H. (1990). He-said-she-said. Bloomington and Indianapolis: Indiana University Press.

Goodwin, M. H. (2006). Participation, affect, and trajectory in family directive/response sequences. Text \& Talk, 26, 515-543.

Goodwin, M. H., \& Goodwin, C. (2001). Emotion within situated activity. In A. Duranti (Ed.), Linguistic anthropology: A reader (pp. 239-257). Malden, MA: Blackwell.

Greer, T., Bussinguer, V., Butterfield, J., \& Mischinger, A. (2009). Receipt through repetition. JALT Journal, 31, 5-34.

Hall, J. K. (2004). Language learning as an interactional achievement. Modern Language Journal, 88, 607-612.

He, A. W. (2004). CA for SLA: Arguments from the Chinese language classroom. Modern Language Journal, 88, 568-582.

Hellermann, J. (2006). Classroom interactive practices for developing L2 literacy: A microethnographic study of two beginning adult learners of English. Applied Linguistics, 27, 377-404.

Hellermann, J. (2007). The development of practices for action in classroom dyadic interaction: Focus on task openings. Modern Language Journal, 91, 83-96.

Hellermann, J. (2009). Social actions for classroom language learning. Clevedon, UK: Multilingual Matters.

Heritage, J., \& Clayman, S. (2010). Talk in action: Interactions, identities, and institutions. Malden, MA: Wiley-Blackwell. 
Heritage, J., \& Raymond, G. (2005). The terms of agreement: Indexing epistemic authority and subordination in talk-in-interaction. Social Psychology Quarterly, 68, 15-38.

Hogan, J. (2004). Are concerns for the addition of English warranted? The Language Teacher, 28(2), 3-8.

Hosoda, Y., \& Aline, D. (2010a). Positions and actions of classroom specific applause. Pragmatics, 20, 133-148.

Hosoda, Y., \& Aline, D. (2010b). Teacher deployment of applause in interactional assessments of L2 learners. In G. Kasper, H. Nguyen, D. R. Yoshimi, \& J. K. Yoshioka (Eds.), Pragmatics and language learning (Vol. 12) (pp. 253-274). Honolulu: University of Hawaii Press.

Jefferson, G. (2004). Glossary of transcript symbols with an introduction. In G. H. Lerner (Ed.), Conversation analysis: Studies from the first generation (pp. 13-31). Amsterdam: John Benjamins.

Kasper, G. (1997). "A" stands for acquisition: A response to Firth and Wagner. Modern Language Journal, 81, 307-312.

Kasper, G. (2004). Participant orientations in German conversation-for-learning. Modern Language Journal, 88, 551-567.

Kelly, C. (2002). Training Japanese elementary school teachers to teach English, The Language Teacher, 26(7), 31-33.

Lantolf, J. P., \& Appel, G. (1994). Vygotskian approaches to second language research. Westport, CT: Ablex.

Lave, J., \& Wenger, E. (1991). Situated learning: Legitimate peripheral participation. Cambridge: Cambridge University Press.

Lerner, G. H. (1993). Collectivities in action: Establishing the relevance of conjoined participation in conversation. Text, 13, 213-245.

Markee, N., \& Kasper, G. (2004). Classroom talks: An introduction. Modern Language Journal, 88, 491-500.

Mori, J., \& Markee, N. (2009). Language learning, cognition, and interactional practices: An introduction. International Review of Applied Linguistics, 47, 1-9.

Murphey, T., Asaoka, C., \& Sekiguchi, M. (2004). Primary teachers co-learning English with their students. The Language Teacher, 28(2), 15-18.

Ochs, E. (1989). Culture and language development: Language acquisition and language socialization in a Samoan village. Cambridge: Cambridge University Press. 
Ochs, E. (1996). Linguistic resources for socializing humanity. In J. J. Gumperz \& S. L. Levinson (Eds.), Rethinking linguistic relativity (pp. 407-437). Cambridge: Cambridge University Press.

Ochs, E., \& Schieffelin, B. B. (1984). Language acquisition and socialization. In R. Shweder \& R. Levine (Eds.), Culture theory: Essays on mind, self, and emotion (pp. 276-320). Cambridge: Cambridge University Press.

Pomerantz, A. (1984). Agreeing and disagreeing with assessments: Some features of preferred/dispreffered turn shapes. In J. M. Atkinson \& J. Heritage (Eds.), Structures of social action: Studies in conversation analysis (pp. 57-101). Cambridge: Cambridge University Press.

Pomerantz, A., \& Fehr, B. J. (1997). Conversation analysis: An approach to the study of social action as sense making practices. In T. A. van Dijk (Ed.), Discourse as social interaction (pp. 64-91). London: Sage.

Raymond, G., \& Heritage, J. (2006). The epistemics of social relations: Owning grandchildren. Language in Society, 35, 677-705.

Sacks, H. (1972). On the analyzability of stories by children. In J. J. Gumperz \& D. Hymes (Eds.), Directions in sociolinguistics: The ethnography of communication (pp. 325-345). New York: Holt, Rinehart, and Winston.

Schegloff, E. A. (1992). On talk and its institutional occasions. In P. Drew \& J. Heritage (Eds.), Talk at work (pp. 101-134). Cambridge: Cambridge University Press.

Schegloff, E. A. (2000). Overlapping talk and the organization of turn-taking for conversation. Language in Society, 29, 1-63.

Schieffelin, B. B., \& Ochs, E., (1986). Language socialization. Annual Review of Anthropology, 15, 163-191.

Searle, J. (1976). The classification of illocutionary acts. Language and Society, 5, $1-24$.

Sinclair, J., \& Coulthard, M. (1975). Towards an analysis of discourse. Oxford: Oxford University Press.

Takagaki, T. (2003). A critical look at elementary school English in Japan from the perspective of the core French program in Ontario, Canada. The Language Teacher, 27(6), 17-19.

van Lier, L. (1998). The relationship between consciousness, interaction and language learning. Language Awareness, 7, 128-145.

Young, R. F., \& Miller, E. R. (2004). Learning as changing participation: Discourse roles in ESL writing conferences. Modern Language Journal, 88, 519-535. 


\section{Appendix}

\section{Transcription Conventions}

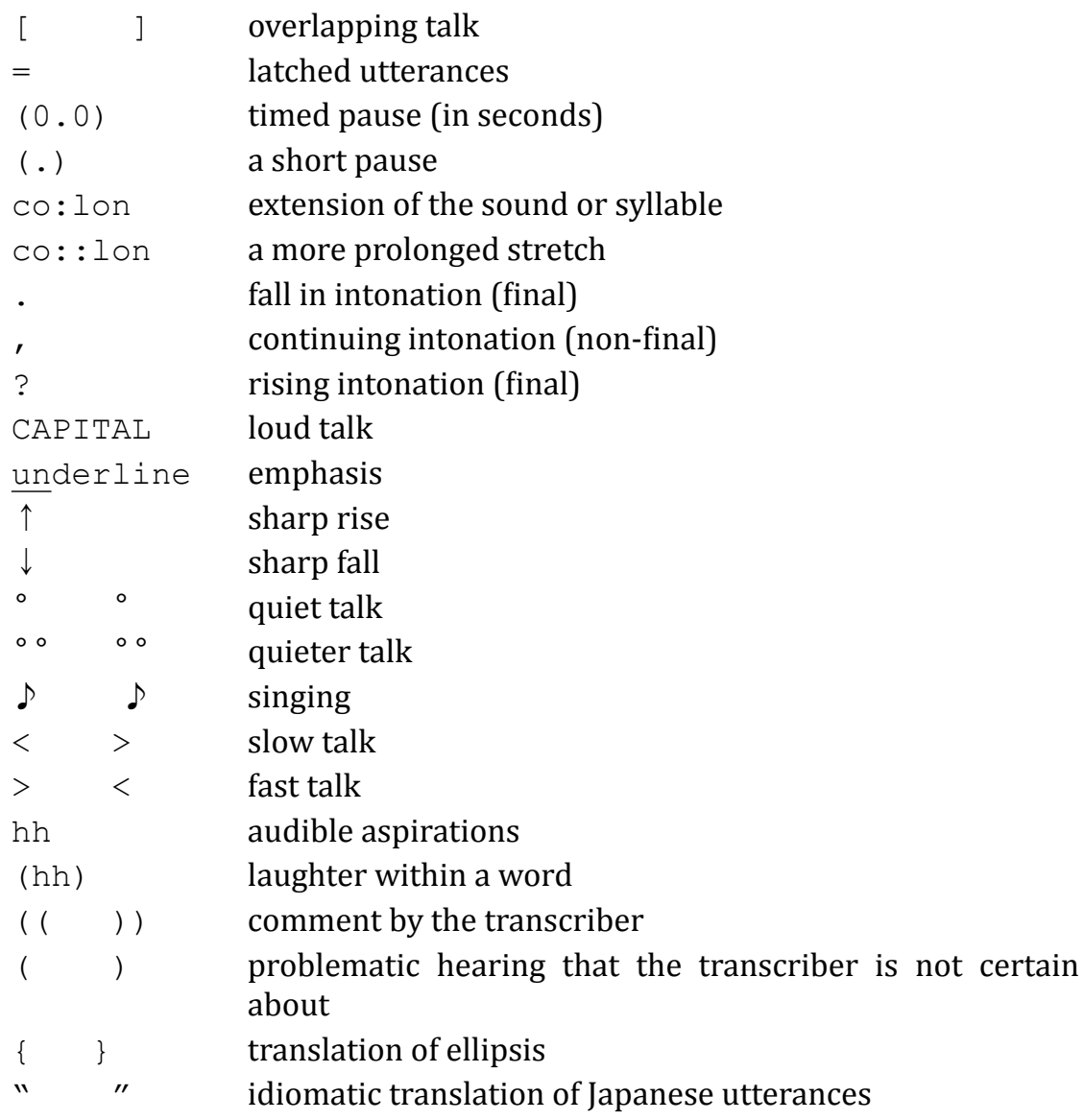


148

JALT Journal, 32.2 • November 2010 